\title{
Analisis Kesesuaian Lahan untuk Padi di Distrik Semangga, Kabupaten Merauke
}

\author{
Land Suitability Analysis for Paddy Field in Semangga District, \\ Merauke Regency
}

\begin{abstract}
ARDIANSYAH ${ }^{1 *}$, SIDHARTA SAHIRMAN ${ }^{1}$, M. RIF'AN ${ }^{2}$, EDY H.P. MELMAMBESSY ${ }^{3}$
${ }^{1}$ Teknik Pertanian, Universitas Jenderal Soedirman, Jl. Dr. Soeparno No. 61, Jawa Tengah 53123; ${ }^{2}$ Agroteknologi, Universitas Jenderal Soedirman, Jl. Dr. Soeparno No. 61, Jawa Tengah 53123; ${ }^{3}$ Budidaya Perikanan, Universitas Musamus, Jl. Kamizaun Mopah Lama, Rimba Jaya, Kec. Merauke, Kabupaten Merauke, Papua 99611; *Penulis korespondensi, e-mail: ardi.plj@gmail.com, cc: ard@ unsoed.ac.id
\end{abstract}

(Diterima: 20 Oktober 2016; Disetujui: 5 Janauri 2017)

\begin{abstract}
This study aimed to determine the land suitability for paddy plantation in Semangga subdistrict, Merauke Regency, Рариa Province and to identify any treatments that needs to be taken to promote the land suitability classes. The information on land suitability is important to determine the treatment required in land preparation in order to achieve optimal production. Survey was conducted to collect necessary data which includes climate data, nutrient content ( $N$, $P, K$ available), Cation Exchange Capacity (CEC), pH, and toxicity. These data are interpolated within the area of Semangga subdistrict and classified based on the criteria developed by Indonesian Soil Research Institute - Ministry of Agriculture and FAO. Overlay analysis is performed in order to determine land suitability classes and the dominant limiting factor. Criteria for determining the suitability classes was taken from the lowest class of land unit. The results showed that the area of 1\% (360.09 hectare) is classified as class of S2wfn, 55.8\% (19,495.83 hectare) as class of S3n, 7\% (2,431.83 hectare) as class of S3np, 35.3\% (12,349.74 hectare) as class N1n, and 0.9\% (306.6 hectare) as class of N2f. The finding of land suitability classes and its dominant inhibitory factor can be used then to determine the proper land treatment planning such as fertilization, liming, and drainage system design.
\end{abstract}

Keywords: land suitability analysis, paddy field, Semangga subdistrict - Merauke Regency

\begin{abstract}
ABSTRAK
Penelitian ini bertujuan menentukan kesesuaian lahan untuk tanaman padi di Distrik Semangga, Kabupaten Merauke, Provinsi Papua dan menetapkan perlakuan-perlakuan yang diperlukan untuk mengingkatkan kelas kesesuaian lahan tersebut. Kesesuaian lahan tersebut penting untuk menentukan perlakuan yang diperlukan dalam menyiapkan lahan agar mampu berproduksi secara optimal. Survei lokasi dilakukan untuk mengambil data-data yang diperlukan, diantaranya data iklim, kandungan hara (N, P, K tersedia), Kapasitas Tukar Kation (KTK), pH dan toksisitas. Data-data tersebut diinterpolasi untuk luasan Distrik Semangga dan dikelaskan berdasarkan kriteria Pusat Penelitian Tanah dan Agroklimat, Balai Penelitian Tanah, Kementerian Pertanian (1993) dan FAO (1976). Analisis tumpang susun (overlay) dilakukan untuk menentukan kelas kesesuaian lahan dan faktor pembatas dominan. Kriteria penentuan kelas kesesuaian diambil yang terendah. Hasil analisis menunjukkan wilayah sebesar 1\% (360.09 ha) berada pada kelas
\end{abstract}


S2wfn, 55.8\% (19.495,83 ha) berada pada kelas S3n, 7\% (2,431.83 ha) berada pada kelas S3np, $35.3 \%$ (12,349.74 ha) berada pada kelas N1n dan 0.9\% (306.6 ha) berada pada kelas kesesuaian lahan N2f. Dengan adanya nilai kelas kesesuaian lahan beserta faktor penghambat yang dominan, dapat dilakukan perencanaan untuk perlakuan lahan seperti pemupukan, pengapuran dan pengaturan drainase.

Kata kunci: pertanian padi, analisis kesesuaian lahan, Distrik Semangga-Kabupaten Merauke

\section{PENDAHULUAN}

\section{Latar Belakang}

Perencanaan Kabupaten Merauke sebagai sentra produksi beras (Kementerian Pertanian 2015) memerlukan pengkajian mendalam mengenai potensi lahan. Pada umumnya kondisi topografis lahan Kabupaten Merauke adalah datar, sehingga dikatakan sangat baik untuk pertanian padi dengan aplikasi mekanisasi intensif. Ketersediaan air di Kabupaten Merauke cukup baik dengan kondisi rawa pasang surut. Produktivitas lahan padi menurut petani setempat antara 3 sampai 5 ton/ha, sehingga dapat disimpulkan bahwa Kabupaten Merauke sangat sesuai untuk tanaman padi.

Di sisi lain, ada beberapa kondisi di Kabupaten Merauke, khususnya Distrik Semangga, yang kondisi tersebut dapat mempengaruhi produktivitas tanaman padi. Salah satu kondisi tersebut diantaranya air payau yang menghambat pengambilan hara tanaman. Hal ini mendorong untuk mencari lebih lanjut apakah ada kondisi lain yang dapat menurunkan produktivitas padi.

Perencanaan lahan adalah aktivitas yang dilakukan setelah suatu lokasi ditetapkan akan digunakan untuk pertanian. Sebelum dilakukan perencanaan lahan, maka penilaian kesesuaian lahan perlu dilakukan. Penilaian kesesuaian lahan menghasilkan kemampuan lahan dan alternatif-alternatif potensial untuk tanaman tertentu (Mokarram dan Aminzadeh, 2010). Analisis yang lebih mendalam dengan mengumpulkan parameter-parameter tanah sangat diperlukan untuk mengenali kondisi terkini dan kemungkinan perbaikan-perbaikan. Analisis kesesuaian lahan dirasakan dapat memberikan keterangan yang komperehensif dan dapat memberikan informasi secara spasial. Informasi mengenai kondisi terkini (present land use) dibutuhkan dalam analisis kesesuaian lahan aktual dan potensial (Djaenudin, 2003; FAO, 1976; Center for Soil Research (CSR)/FAO, 1983).

Analisis kesesuaian lahan untuk Kabupaten Merauke pernah dilakukan sebelumnya (Marfai, 2012; Mardawilis et al., 2011; Marwoto dan Candra, 2007). Namun semua analisis kesesuaian lahan tersebut mencakup wilayah yang luas, misalnya daerah Papua Barat secara keseluruhan, atau tidak spesifik pada tanaman padi. Analisis kesesuaian lahan yang secara spesifik dilakukan untuk distrik-distrik di Kabupaten Merauke belum ditemukan. Pada kenyataannya, Distrik Semangga sedang intensif dikembangkan, sehingga sangat diperlukan data dan rekomendasi untuk perencanaan pertanian padi.

\section{Tujuan Penelitian}

Penelitian ini bertujuan: (1) mendapatkan informasi mengenai kelas-kelas keseuaian lahan yang ada di Distrik Semangga, Kabupaten Merauke, untuk penanaman padi sawah dan (2) menetapkan perlakuan-perlakuan yang diperlukan untuk meningkatkan kelas kesesuaian lahan terhadap tanaman padi.

\section{METODE PENELITIAN}

Diagram alir analisis kesesuaian lahan dapat dilihat pada Gambar 1. Peta geologi yang menunjukkan bahan induk pembentuk tanah diperoleh dari Pusat Penelitian dan Pengembangan Geologi Kelautan (P3GL), Kementerian Energi dan Sumber daya Mineral, 
Bandung. Skala peta yang tersedia untuk Papua tidak tersedia yang lebih detil dari 1:250,000, sehingga digunakan dalam analisis. Peta Tata Guna Lahan diperoleh dengan prosedur supervised classification terhadap citra Landsat 8 (Ardiansyah et al., 2015; Mosleh et al., 2015). Citra Landsat sendiri diketahui memiliki resolusi spasial sebesar 30 meter/pixel, sehingga skala dapat didekati pada nilai $1: 60,000$.

Secara teknis, proses overlay kedua peta tersebut dilakukan dengan terlebih dahulu melakukan geo-rektifikasi pada Peta geologi dalam perangkat lunak Sistem Informasi Geografis (SIG) dengan transformasi linear. Peta tata guna lahan yang sudah diproses sebelumnya ditumpangsusunkan (overlay) dengan Peta Geologi dengan operasi perkalian raster.

Kondisi topografi di Kabupaten Merauke relatif datar (Ito et al., 2014), sehingga penggunaan peta topografi untuk membuat peta satuan lahan tidak diperlukan. Peta satuan lahan menjadi dasar pengambilan sampel ketika survei. Skala peta satuan lahan ini mengikuti skala peta tata guna lahan, demikian juga peta kesesuaian lahan.

Data tanah dan iklim diperoleh dengan melakukan survei terhadap 16 titik sample yang mewakili satuan lahan di Distrik Semangga Skala pengambilan data adalah 1 sampel untuk tiap 2,184 ha. Kerapatan ini mendekati survei tanah tingkat "tinjau". Data ini dicocokkan dengan kriteria kesesuaian lahan untuk tanaman padi (syarat tumbuh tanaman padi). Perangkat lunak yang digunakan dalam penelitian ini adalah GRASS GIS (Dassau et al., 2005;
Neteler dan Mitasova, 2004; Neteler et al., 2012).

Syarat tumbuh tanaman yang diterapkan pada penelitian ini menggunakan panduan dari Pusat Penelitian Tanah dan Agroklimat (Puslittanak) (1993) mengenai petunjuk teknis evaluasi lahan. Pada dasarnya pengklasifikasian mengikuti Food and Agriculture Organization of the United Nations (FAO) yang menggunakan 2 ordo, yaitu sesuai $(\mathrm{S})$, dan tidak sesuai $(\mathrm{N})$. Ordo $\mathrm{S}$ terbagi menjadi 3 sub-kelas; sangat sesuai (S1), cukup sesuai (S2), dan sesuai marjinal (S3). Ordo N terbagi menjadi 2 sub kelas, yaitu: tidak sesuai saat ini (N1), dan tidak sesuai permanen (N2). Kriteria tumbuh tanaman memiliki beberapa sub-kelas yang akan dicocokkan dengan kondisi lahan yang diteliti. Kriteria tumbuh tanaman padi dapat dilihat pada Tabel 1. Hasil akhir analisis kesesuaian lahan adalah peta kesesuaian lahan untuk komoditas yang diinginkan, dalam hal ini padi.

Beberapa algoritma analisis kesesuaian lahan menggunakan metode Analytic Hierarchy Process (AHP) (Akınc1 et al., 2013), namun metode ini lebih rumit untuk diterapkan dan memerlukan expert untuk menetapkan kriteriakriteria. Algoritma lainnya menggunakan alat pengembang perangkat lunak berbayar, misalnya Agricultural Land Suitability Evaluator (ALSE) (Elsheikh et al., 2013) sehingga tidak dapat terjangkau untuk semua orang. Kesesuaian lahan pada penelitian ini menggunakan metode pencocokan, sehingga lebih sederhana dan mudah diaplikasikan dibandingkan metode lain. Selain itu perangkat lunak yang digunakan adalah perangkat lunak yang tersedia bebas di dunia maya. 


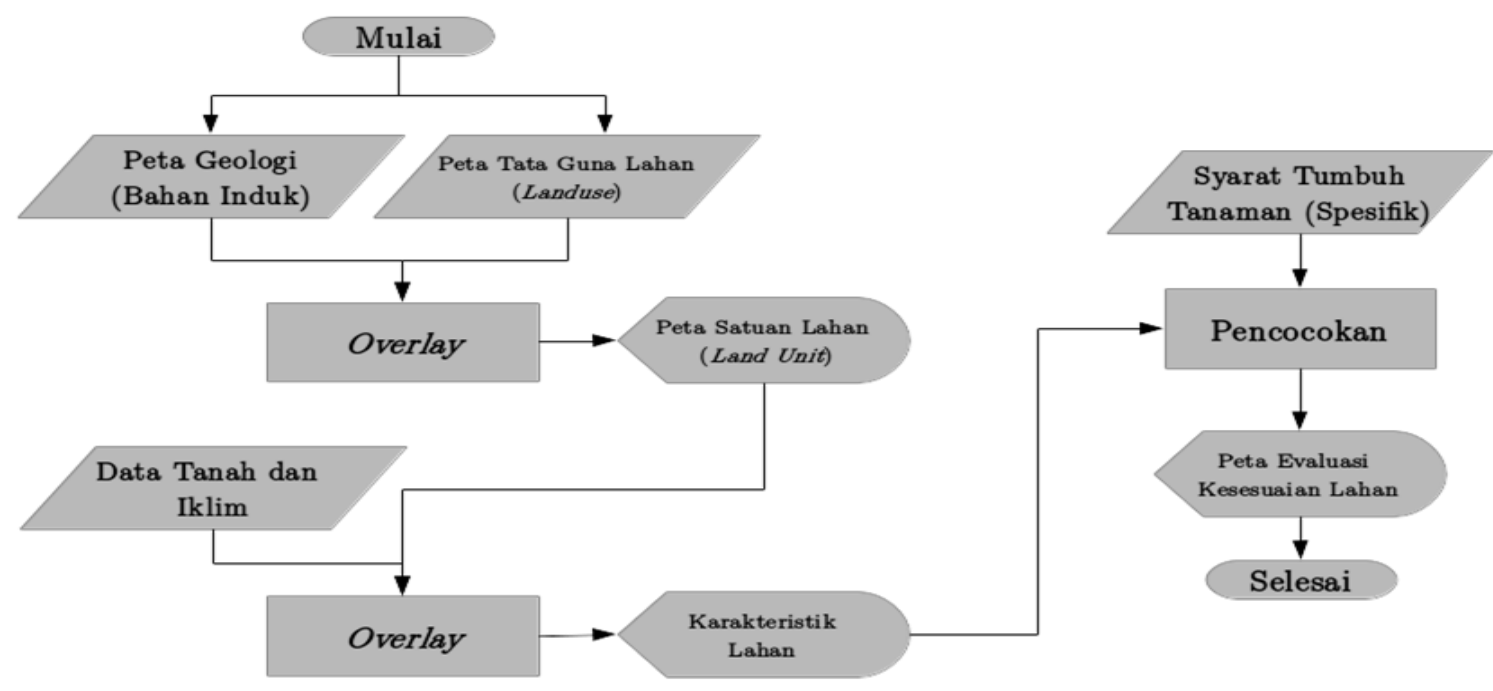

Gambar 1. Diagram alir analisis kesesuaian lahan

\section{HASIL DAN PEMBAHASAN}

\section{Survey Lokasi dan Pengambilan Sampel Tanah}

Data yang diperoleh di lapangan di plot pada peta Distrik Semangga. Data titik pada pengambilan sampel menggambarkan variabilitas spasial pada lokasi penelitian. Variabilitas spasial di Distrik Semangga dapat diketahui dengan menginterpolasi data-data titik tersebut. Interpolasi dilakukan dengan menggunakan metode spline (Mitasova et al., 2005; Kong dan Ong, 2009; Neteler dan Mitasova, 2004). Perbandingan sebaran spasial sifat kimia tanah (Total N, P tersedia, K tersedia, EC dan $\mathrm{pH}$ ) dapat diamati pada Gambar 2. Peta ini tidak digunakan dalam analisis kesesuaian lahan, namun digunakan sebagai bahan observasi untuk mendapatkan gambaran singkat hasil survei sifat-sifat lahan. Umumnya, nilai-nilai pada lahan akan digunakan sebagai indikasi kelas lahan untuk masing-masing parameter yang dimuat pada Tabel 1 (Sarkar et al., 2014). Batas-batas area pengkategorian kelas kesesuaian lahan adalah peta satuan lahan.

\section{Peta Satuan Lahan}

Peta satuan lahan adalah hasil overlay Peta tata guna lahan dengan peta bahan induk penyusun lahan. Tata guna lahan dan tutupan lahan yang diperoleh dari citra satelit sangat penting dalam penentuan kesesuaian lahan (Ayehu dan Besufekad, 2015). Dasar pengambilan titik-titik sampel dominan ditentukan oleh peta tata guna lahan, karena bahan induk pembentuk lahan tidak memiliki variabilitas spasial yang berarti. Peta lereng tidak digunakan dalam pembuatan Peta Satuan Lahan, karena kondisi lahan di Kabupaten Merauke yang relatif datar (Ito et al., 2014; Wambrauw, 2015). Peta satuan lahan perlu dibuat untuk mengelompokkan satuan-satuan lahan yang mempunyai sifat homogen (Budiarta, 2016). Tiap-tiap satuan lahan diasumsikan mempunyai sifat-sifat yang sama, karena berasal dari bahan induk penyusun yang sama dan memiliki tata guna lahan yang sama. Berdasarkan asumsi ini, peta satuan lahan akan digunakan sebagai dasar dalam menentukan kelas kesesuaian lahan. 
Tabel 1. Syarat tumbuh tanaman padi sawah

\begin{tabular}{|c|c|c|c|c|c|c|}
\hline \multirow{2}{*}{\multicolumn{2}{|c|}{$\begin{array}{c}\text { Kualitas/ } \\
\text { Karakteristik Lahan }\end{array}$}} & \multicolumn{5}{|c|}{ Kelas Kesesuaian } \\
\hline & & \multirow{2}{*}{$\frac{\text { S1 }}{24-29}$} & \multirow{2}{*}{$\begin{array}{c}\text { S2 } \\
22-24 \\
29-32\end{array}$} & \multirow{2}{*}{$\begin{array}{c}\text { S3 } \\
18-22 ; \\
32-35\end{array}$} & \multirow{2}{*}{$\begin{array}{l}\text { N1 } \\
\mathrm{Td}\end{array}$} & \multirow{2}{*}{$\begin{array}{l}\mathbf{N 2} \\
>35 ; \\
<18\end{array}$} \\
\hline Temperatur (t) & $\begin{array}{l}\text { Temperatur rerata } \\
\text { tahunan }\left({ }^{\circ} \mathrm{C}\right)\end{array}$ & & & & & \\
\hline \multirow[t]{2}{*}{$\begin{array}{l}\text { Ketersediaan air } \\
(\mathrm{w})\end{array}$} & $\begin{array}{l}\text { Bulan kering } \\
(<75 \mathrm{~mm})\end{array}$ & $<3$ & $3-9$ & $9-9.5$ & $\mathrm{Td}$ & $>9.5$ \\
\hline & $\begin{array}{l}\text { Curah hujan/tahun } \\
\text { (mm) }\end{array}$ & $>1500$ & $1200-1500$ & $800-1200$ & & $<800$ \\
\hline \multirow[t]{6}{*}{$\begin{array}{l}\text { Media } \\
\text { Perakaran (r) }\end{array}$} & Drainase tanah & Terhambat & Terhambat & $\begin{array}{l}\text { Sedang, } \\
\text { Baik }\end{array}$ & Cepat & $\begin{array}{c}\text { Sangat } \\
\text { Cepat }\end{array}$ \\
\hline & Tekstur & $\begin{array}{l}\text { SCL, SiL, } \mathrm{Si}, \\
\text { CL }\end{array}$ & $\begin{array}{l}\text { SL, L, SiCL, } \\
\text { SiC, Str C }\end{array}$ & $\begin{array}{l}\text { LS, Liat } \\
\text { Masif }\end{array}$ & $\mathrm{Td}$ & $\begin{array}{l}\text { Kerikil, } \\
\text { Pasir }\end{array}$ \\
\hline & $\begin{array}{l}\text { Kedalaman tanah } \\
\text { efektif }(\mathrm{cm})\end{array}$ & $>50$ & $40-50$ & $25-40$ & $<25$ & $<20$ \\
\hline & Gambut & & & & & \\
\hline & - Kematangan & - & Satrik & Hemik & & Fibrik \\
\hline & - Ketebalan (cm) & - & $<100$ & $100-150$ & & $>200$ \\
\hline \multirow[t]{2}{*}{ Retensi Hara (f) } & KTK & $\geq$ Sedang & Rendah & $\begin{array}{l}\text { Sangat } \\
\text { Rendah }\end{array}$ & $\mathrm{Td}$ & $\mathrm{Td}$ \\
\hline & $\overline{\mathrm{pH} \mathrm{H}} \mathrm{H}_{2} \mathrm{O}$ & $5.5-7$ & $\begin{array}{l}4.5-5.5 \\
7-8\end{array}$ & $\begin{array}{l}4-4.5 \\
8-8.5\end{array}$ & $\mathrm{Td}$ & $\begin{array}{l}>8.5 \\
<4.0\end{array}$ \\
\hline Salinitas (c) & $\mathrm{EC}(\mathrm{mmhos} / \mathrm{cm})$ & $<3.5$ & $3.5-5.0$ & $5.0-6.6$ & $6.6-8$ & $>8$ \\
\hline \multirow[t]{2}{*}{ Toksisitas (x) } & Kejenuhan $\mathrm{Al}(\%)$ & & & & & \\
\hline & $\begin{array}{l}\text { Kedalaman } \\
\text { Sulfidik }(\mathrm{cm})\end{array}$ & $>75$ & $60-75$ & $40-60$ & $30-40$ & $<30$ \\
\hline \multirow[t]{3}{*}{$\begin{array}{l}\text { Hara Tersedia } \\
\text { (n) }\end{array}$} & Total N & $\geq$ Sedang & Rendah & $\begin{array}{l}\text { Sangat } \\
\text { Rendah }\end{array}$ & & \\
\hline & $\mathrm{P}_{2} \mathrm{O}_{5}$ & Sangat Tinggi & Tinggi & $\begin{array}{l}\text { Sedang - } \\
\text { Rendah }\end{array}$ & $\begin{array}{l}\text { Sangat } \\
\text { Rendah }\end{array}$ & \\
\hline & $\mathrm{K}_{2} \mathrm{O}$ & $\geq$ Sedang & Rendah & $\begin{array}{l}\text { Sangat } \\
\text { Rendah }\end{array}$ & & \\
\hline $\begin{array}{l}\text { Kemudahan } \\
\text { Pengolahan (p) }\end{array}$ & Tekstur & $\begin{array}{l}\text { SL, L, SCL, } \\
\text { SiL, Si, CL, } \\
\text { SiCL }\end{array}$ & LS, SC & $\mathrm{SiC}, \mathrm{Str}$ & & $\begin{array}{c}\text { gravely, LS, } \\
\mathrm{S}, \text { massive } \\
\text { clay }\end{array}$ \\
\hline \multirow{3}{*}{$\begin{array}{l}\text { Terrain/Potensi } \\
\text { Mekanisasi (s) }\end{array}$} & Lereng $(\%)$ & $<3$ & $3-5$ & $5-8$ & $\mathrm{Td}$ & $>8$ \\
\hline & $\begin{array}{l}\text { Batuan di } \\
\text { permukaan }(\%)\end{array}$ & $<2$ & $2-5$ & $5-10$ & $10-25$ & $>25$ \\
\hline & $\begin{array}{l}\text { Singkapan batuan } \\
(\%)\end{array}$ & 0 & $2-5$ & $5-15$ & $\mathrm{Td}$ & $>15$ \\
\hline Bahaya erosi (e) & & $\begin{array}{l}\text { Sangat } \\
\text { Rendah }\end{array}$ & Rendah & Sedang & Berat & Sangat Berat \\
\hline Bahaya banjir (b) & & $\mathrm{F} 0-\mathrm{F} 1$ & $\mathrm{~F} 2$ & F3 & $\mathrm{F} 4$ & $\mathrm{~F} 4$ \\
\hline
\end{tabular}

*Keterangan: Td = Tidak berlaku, C = Clay; L = Loam; $\mathrm{Si}=$ Silt; $\mathrm{S}=$ Sand; $\mathrm{Str} \mathrm{C}=$ Structured Clay Sumber: Pusat Penelitian Tanah dan Agroklimat (Puslittanak), 1993.

Peta bahan induk penyusun lahan bahan induk, dan kemiringan masing-masing diperoleh dari Pusat Penelitian dan [Tabel 2]. Pengembangan Geologi Kelautan (P3GL), Peta tata guna lahan [Gambar 3], Kementerian Energi dan Sumber Daya Mineral, diperoleh dengan melakukan prosedur Bandung. Analisis overlay menghasilkan supervised classification pada citra satelit beberapa kode satuan lahan dengan tata guna, Lansdsat 8 . Kombinasi band yang digunakan untuk mendapatkan peta landuse adalah Band 
6, Band 5, dan Band 2 (Agricultural Band). Kombinasi band ini lebih baik dalam mengklasifikasi tata guna lahan dibandingkan kombinasi band lainnya (Ardiansyah et al., 2015).

Bahan induk penyusun lahan pada Distrik Semangga pada dasarnya adalah rawa dan sungai. Hasil tumpang susun dengan landuse

a)

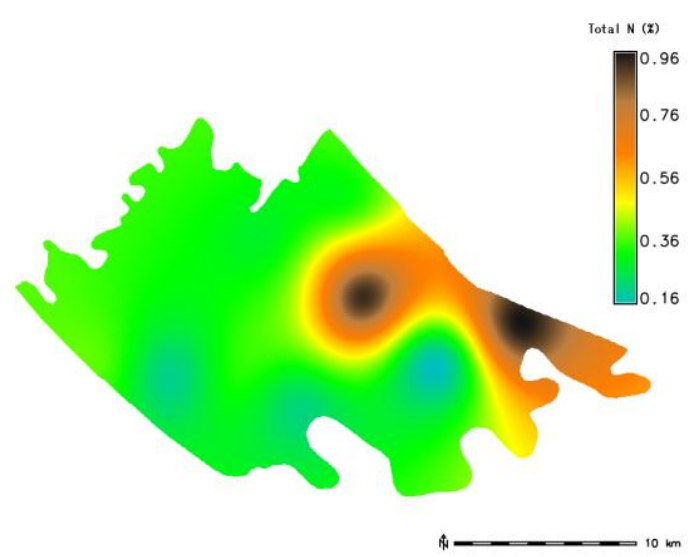

b)

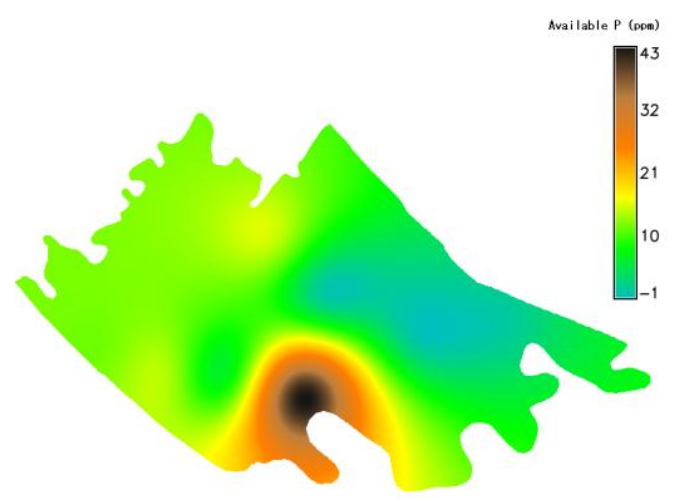

c)

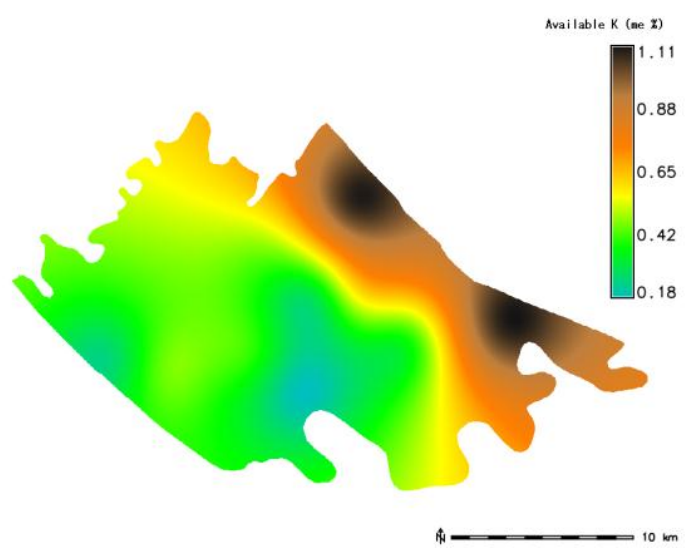

menghasilkan 12 satuan lahan [Gambar 4a], yang kemudian diklasifikasi menjadi 7 satuan lahan [Gambar 4b], yaitu Qrp, Qrf, Qrsf, Qsp, Qsf, Qssf, dan V. Peta satuan lahan ini menjadi dasar untuk menempatkan kelas-kelas kesesuaian lahan berdasarkan syarat tumbuh tanaman.

d)

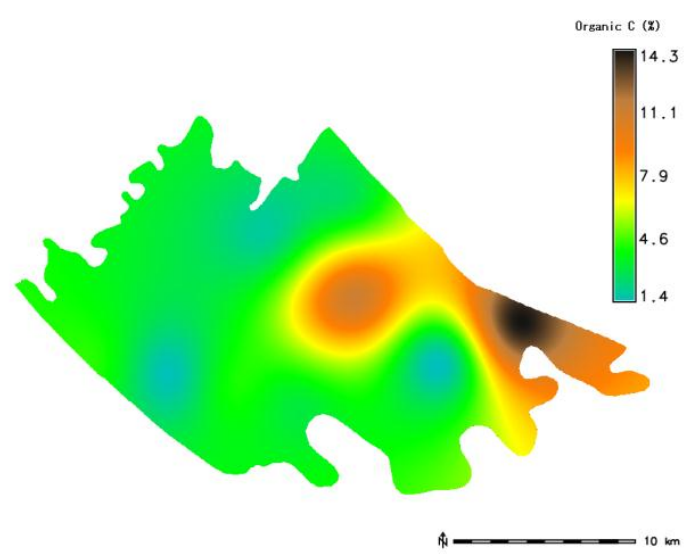

e)

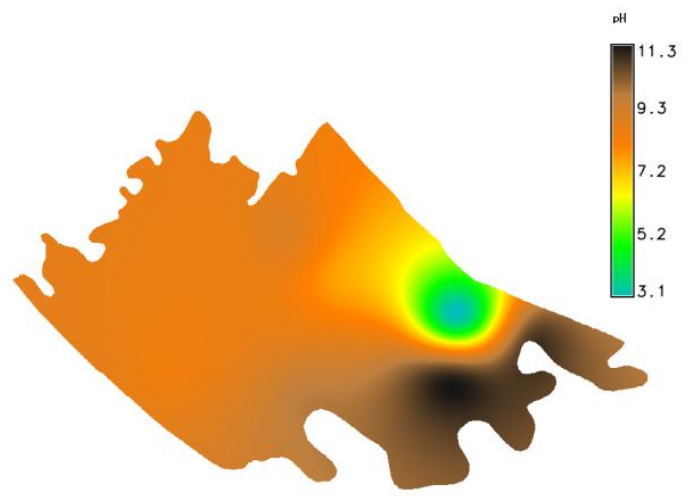

f)

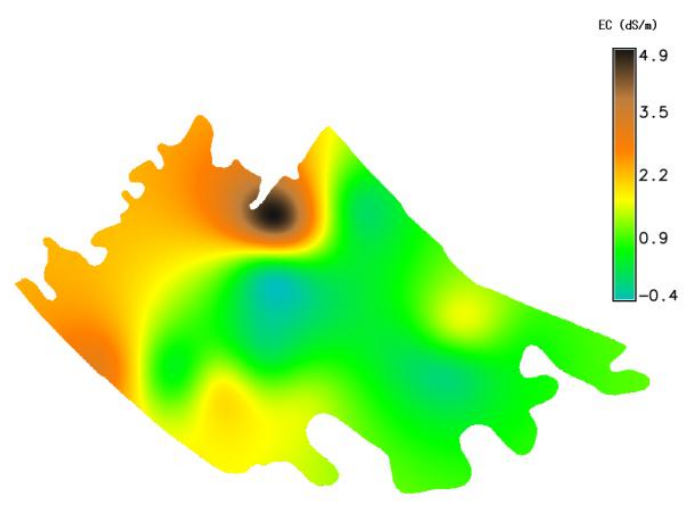

Gambar 2. Sebaran Parameter: a) Total N; b) P tersedia; c) K tersedia; d) C-organik; e) $\mathrm{pH}$; f) EC pada Distrik Semangga

Sumber: Hasil analisis, 2016. 


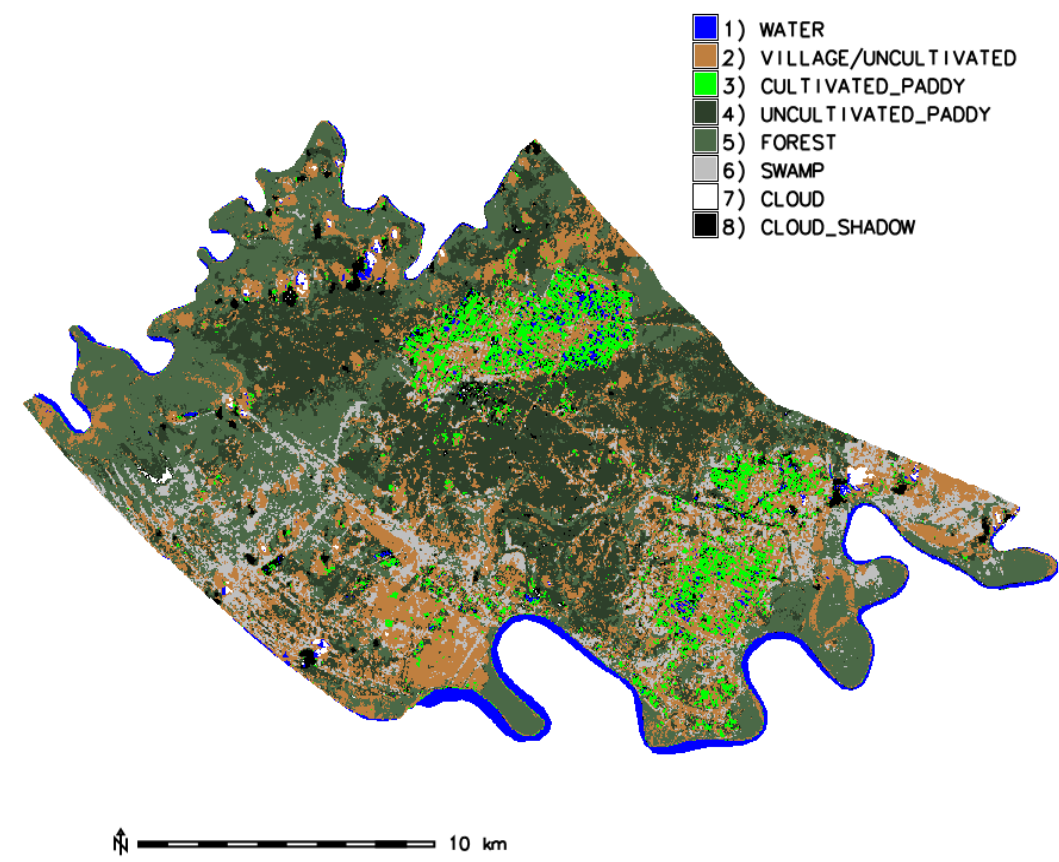

Gambar 3. Tata guna lahan pada Distrik Semangga Sumber: Ardiansyah et al., 2015.

a)

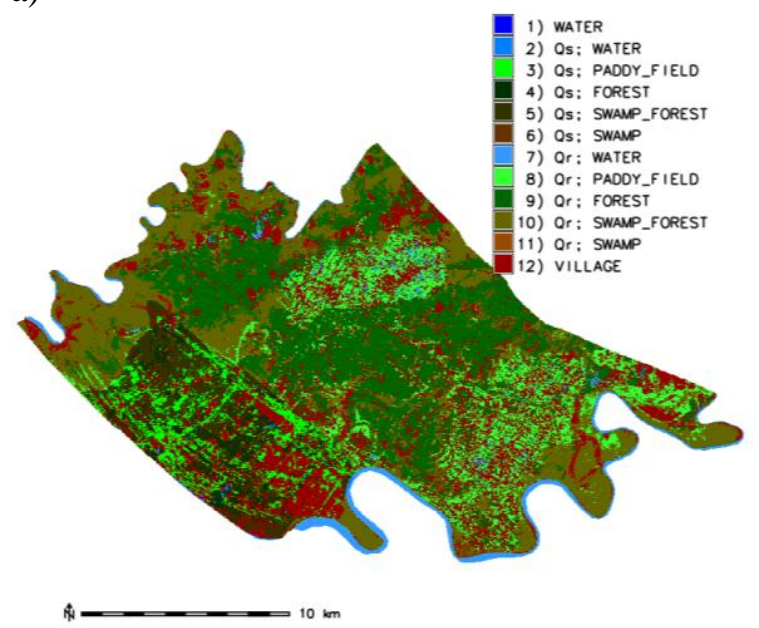

b)

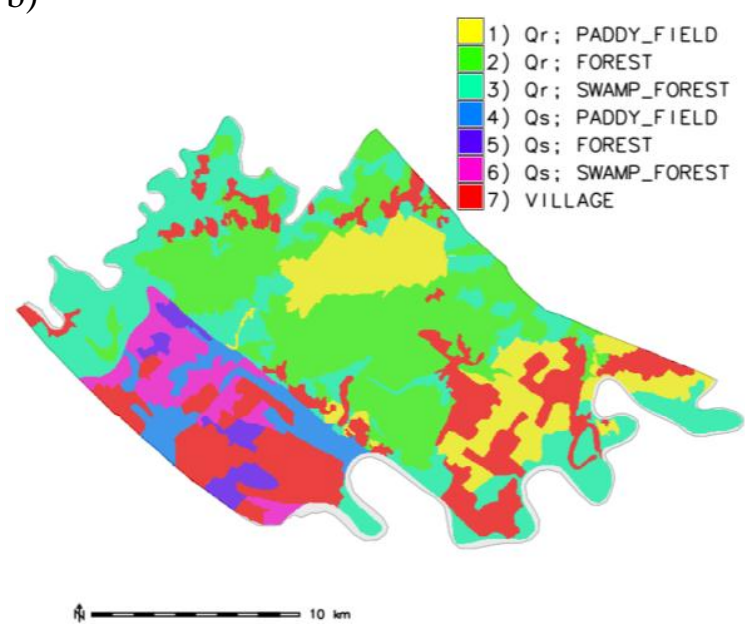

Gambar 4. Peta satuan lahan:

a) Overlay peta bahan induk penyusun lahan dan peta tata guna lahan;

b) Peta satuan lahan hasil pengelompokan Sumber: Hasil analisis, 2016.

Tabel 2. Satuan lahan di Distrik Semangga

\begin{tabular}{|c|c|c|c|c|c|}
\hline No SLH & $\begin{array}{c}\text { Kode Satuan } \\
\text { Lahan }\end{array}$ & Landform & $\begin{array}{l}\text { Tata Guna } \\
\text { Lahan }\end{array}$ & Bahan Induk & $\begin{array}{c}\text { Kemiringan } \\
(\%)\end{array}$ \\
\hline 1 & Qrp & Rawa belakang pasang surut & Padi sawah & Pasir, lumpur dan kerikil & $1-3$ \\
\hline 2 & Qrf & Rawa belakang pasang surut & Hutan & Pasir, lumpur dan kerikil & $1-3$ \\
\hline 3 & Qrsf & Rawa belakang pasang surut & Hutan rawa & Pasir, lumpur dan kerikil & $1-3$ \\
\hline 4 & Qsp & Pantai pasang surut lumpur & Padi sawah & $\begin{array}{l}\text { Lumpur dan pasir halus } \\
\text { berkarbon }\end{array}$ & $0-2$ \\
\hline
\end{tabular}


Tabel 2. (lanjutan)

\begin{tabular}{cccclc}
\hline No SLH & $\begin{array}{c}\text { Kode Satuan } \\
\text { Lahan }\end{array}$ & \multicolumn{1}{c}{ Landform } & $\begin{array}{c}\text { Tata Guna } \\
\text { Lahan }\end{array}$ & \multicolumn{1}{c}{ Bahan Induk } & $\begin{array}{c}\text { Kemiringan } \\
(\%)\end{array}$ \\
\hline 5 & Qsf & Pantai pasang surut lumpur & Hutan & $\begin{array}{l}\text { Lumpur dan pasir halus } \\
\text { berkarbon }\end{array}$ & $0-2$ \\
6 & Qssf & Pantai pasang surut lumpur & Hutan rawa & $\begin{array}{l}\text { Lumpur dan pasir halus } \\
\text { berkarbon }\end{array}$ & $0-2$ \\
7 & V & Desa & & $0-3$ \\
\hline
\end{tabular}

Sumber: Hasil analisis, 2016.

\section{Kelas Kesesuaian Lahan untuk Padi}

Kelas kesesuaian lahan untuk padi diperoleh dengan pencocokan kebutuhan tanaman dengan kualitas lahan. Informasi kebutuhan tanaman mencakup parameter tanah dan iklim yang dapat mempengaruhi pertumbuhan tanaman (Elseikh, 2015). Analisis kesesuaian lahan menghasilkan peta pada Gambar 5. Ada lima kelas yang muncul, yaitu
S2wfn, S3n, S3np, N1n, dan N2f. Dari lima kelas tersebut, diketahui faktor pembatas untuk tanaman padi pada Distrik Semangga, Kabupaten Merauke adalah ketersediaan air (w), retensi hara (f), hara tersedia (n), kemudahan pengolahan (p). Detil dari kelaskelas tersebut dan keterangannya dapat dilihat pada Tabel 3 .

Tabel 3. Kelas kesesuaian lahan dan keterangannya

\begin{tabular}{|c|c|c|c|}
\hline $\begin{array}{l}\text { Kelas Kesesuaian } \\
\text { Lahan }\end{array}$ & $\begin{array}{l}\text { Luas Area } \\
\text { (ha) }\end{array}$ & $\begin{array}{c}\text { Persentase Area } \\
(\%)\end{array}$ & Keterangan \\
\hline S2wfn & 360.9 & 1 & $\begin{array}{l}\text { Cukup sesuai, pembatas ketersediaan air, } \\
\text { retensi hara, nutrisi }\end{array}$ \\
\hline S3n & $19,495.83$ & 55.8 & Sesuai marjinal, pembatas nutrisi \\
\hline S3np & $2,431.83$ & 7 & $\begin{array}{l}\text { Sesuai marjinal, pembatas nutrisi, kemudahan } \\
\text { pengolahan }\end{array}$ \\
\hline N1n & $12,349.74$ & 35.3 & Tidak sesuai saat ini, pembatas nutrisi \\
\hline $\mathrm{N} 2 \mathrm{f}$ & 306.6 & 0.9 & Tidak sesuai permanen, pembatas, retensi hara \\
\hline
\end{tabular}

Sumber: Hasil analisis, 2016.

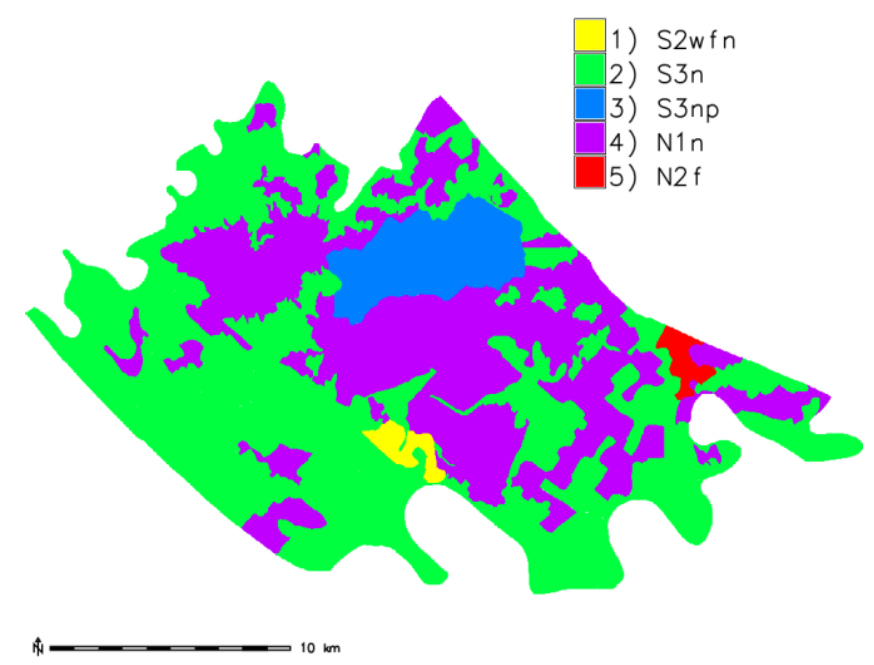

Gambar 5. Kelas kesesuaian lahan untuk padi Sumber: Hasil analisis, 2016. 


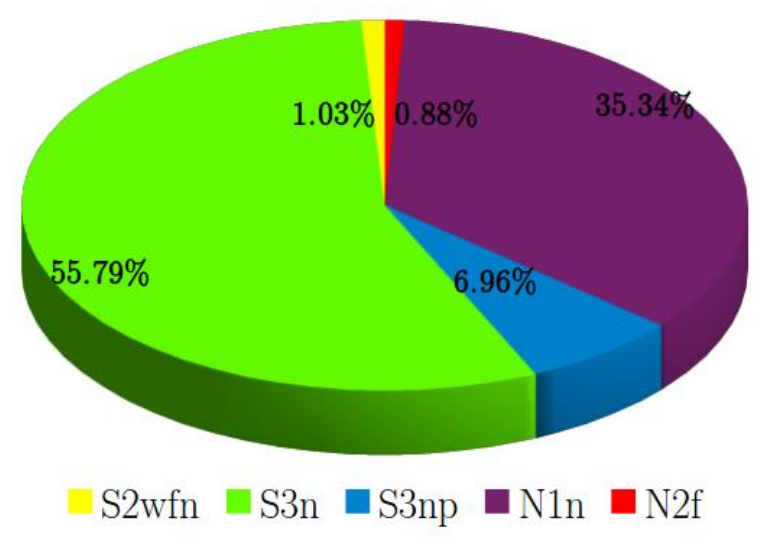

Gambar 6. Kelas kesesuaian lahan untuk padi sawah dan persentasenya Sumber: Hasil analisis, 2016.

Gambar 6 menunjukkan sebagian besar lokasi Distrik Semangga memiliki kelas kesesuaian S3n, yaitu sebanyak $55 \%$ dan memiliki luas 19,495.83 ha. Pengamatan terhadap data tanah menunjukkan faktor pembatas $\mathrm{n}$ (ketersediaan hara) adalah pada ketersediaan unsur hara $\mathrm{P}$. Jumlah unsur hara $\mathrm{P}$ pada kelas tersebut berada pada harkat rendah hingga sedang. Perbaikan dari S3 menjadi S2 dapat dilakukan dengan memberikan pupuk $\mathrm{P}$, sehingga harkat unsur hara $\mathrm{P}$ menjadi tinggi. Perbaikan drainase akan meningkatkan kelas menjadi S2fn. Disamping itu, kelas kesesuaian lahan S3np yang memiliki luas sebesar 2,431.83 (6.96\%) juga dapat diperbaiki menjadi S2np dengan aplikasi pupuk $\mathrm{P}$ dan perbaikan drainase lahan. Potensi perbaikan ini akan meningkatkan ketersediaan lahan dengan kelas kesesuaian S2 dari hanya 1\%, menjadi 63.8\% atau sebanyak 22,287.75 ha.

Tanah dengan kelas kesesuaian N1n, ketika hara $\mathrm{P}$ sangat rendah, dapat ditingkatkan menjadi S3np apabila diberikan pupuk $\mathrm{P}$ dan sistem drainase diperbaiki. Pada tanah dengan kesesuaian N2f, perbaikan drainase dan pemupukan $\mathrm{P}$ dapat meningkatkan kelas kesesuaian menjadi S3fn. Pengendalian muka air mutlak diperlukan pada tanah ini untuk mencegah oksidasi pirit pada daerah perakaran. Secara ringkas, potensi perbaikan lahan untuk meningkatkan kelas kesesuaiannya dapat dilihat pada Tabel 4.

Tabel 4. Kelas kesesuaian lahan potensial setelah perbaikan

\begin{tabular}{cclc}
$\begin{array}{c}\text { Kelas } \\
\text { Kesesuaian } \\
\text { Lahan }\end{array}$ & $\begin{array}{c}\text { Persentase } \\
\text { Area } \\
(\mathbf{\%})\end{array}$ & \multicolumn{1}{c}{ Perbaikan Lahan } & $\begin{array}{c}\text { Potensi Kelas } \\
\text { Kesesuaian } \\
\text { Lahan }\end{array}$ \\
\hline S2wfn & 1 & $\begin{array}{l}\text { Perbaikan drainase, pemupukan P hingga pada harkat } \\
\text { "sedang" }\end{array}$ & S2f \\
S3n & 55.8 & $\begin{array}{l}\text { Perbaikan drainase, pemupukan P sehingga harkat P tersedia } \\
\text { tanah rendah-sedang menjadi tinggi }\end{array}$ & S2fn \\
S3np & 7 & $\begin{array}{l}\text { Perbaikan drainase, pemupukan P sehingga harkat P tersedia } \\
\text { tanah rendah-sedang menjadi tinggi } \\
\text { Perbaikan drainase, pemupukan P sehingga harkat P tersedia } \\
\text { tanah sangat rendah menjadi rendah-sedang }\end{array}$ & S2np \\
N2f & 35.3 & $\begin{array}{l}\text { Perbaikan drainase, pengaturan muka air tanah, pemupukan P } \\
\text { sehingga harkat P tersedia sangat rendah menjadi rendah- } \\
\text { sedang }\end{array}$ & S3fn \\
\hline
\end{tabular}

Sumber: Hasil analisis, 2016. 


\section{KESIMPULAN}

Klasifikasi kesesuaian lahan aktual untuk tanaman padi pada Distrik Semangga, Kabupaten Merauke menghasilkan area dengan kelas kesesuaian S2 hingga N2. Kelas tersebut menandakan perlunya perlakuan untuk mendapatkan peningkatan kelas (kesesuaian lahan potensial). Perlakuan untuk peningkatan kelas kesesuaian lahan di Distrik Semangga pada umumnya adalah pemupukan $\mathrm{P}$ dan perbaikan sistem drainase. Melalui perbaikan tersebut kelas kesesuaian lahan S2 dapat meningkat dari 1\% (360.09 ha) menjadi 63.8\% $(22,287.75$ ha). Biaya-biaya yang ditimbulkan untuk perbaikan lahan perlu dianalisis lebih lanjut.

\section{Ucapan Terima Kasih}

Penelitian ini didanai oleh Kementerian Riset, Teknologi dan Pendidikan Tinggi (Kemenristek-Dikti) tahun anggaran 2016, pada skema Master Plan Percepatan Pembangunan Ekonomi Indonesia (MP3EI). Ucapan terima kasih kami sampaikan kepada KemenristekDikti, dan juga kepada Universitas Musamus yang turut memfasilitasi penelitian ini.

\section{DAFTAR PUSTAKA}

Akınc1, H., Özalp, A. Y., \& Turgut, B. (2013). Agricultural Land Use Suitability Analysis Using GIS and AHP Technique. Computers and Electronics in Agriculture, 97, 71-82

Ardiansyah, Sahirman, S., Rif'an, M., \& Melmambessy, E. H. P. Perbandingan Hasil Klasifikasi Tutupan/ Penggunaan Lahan Distrik Semangga dengan Dua Komposisi Spektral Berbeda pada Citra Landsat 8 OLI/TIRS. Prosiding Seminar Lahan SubOptimal 2015. Palembang, pp. $630-639$.

Ayehu, Getachew, T., \& Solomon, A. Besufekad. (2015). Land Suitability Analysis for Rice Production: A GIS Based Multi-Criteria Decision Approach. American Journal of Geographic Information System, 4, 95-104.
Budiarta, I. G. (2016). Suitability Evaluation of Land Use as Efforts to Improve Quality of Watershed. Media Komunikasi Geografi, 17, 28-37.

Center for Soil Research (CSR)/FAO. 1983. Reconnaissance Land Resource Surveys. Bogor.

Dassau, O., Holl, S., \& Neteler, M. (2005) An Introduction to The Practical Use of The Free Geographical Information System GRASS 6.0.

Djaenudin, D. (2003). Petunjuk Teknis Evaluasi Lahan Untuk Komoditas Pertanian. Bogor: Balai Penelitian Tanah, Puslitbangtanak, Badan Penelitian dan Pengembangan Pertanian, Kementerian Pertanian.

Elsheikh, R., Shariff, A. R. B. M., Amiri, F., Ahmad, N. B., Balasundram, S. K., \& Soom, M. A. M. (2013). Agriculture Land Suitability Evaluator (ALSE): A Decision and Planning Support Tool for Tropical and Subtropical Crops. Computers and Electronics in Agriculture, 93, 98-110.

Elsheikh, R. F. A. 2015. GIS Based Land Evaluation Decision Support System. Academia Journal of Agricultural Research, 3, 369-380.

Food and Agriculture Organization of the United Nations (FAO). 1976. A Framework for Land Evaluation. Rome.

Ito, T., Rachman, N. F., \& Savitri, L. A. (2014). Power to Make Land Dispossession Acceptable: A Policy Discourse Analysis of the Merauke Integrated Food and Energy Estate (MIFEE), Papua, Indonesia, Journal of Peasant Studies, 41, 29-50.

Kementrian Pertanian. (2015). Potensi Produksi Pangan Luar Biasa di Merauke. Diakses dari: http://goo.gl/1qLBQO pada tanggal 25 September 2015.

Kong, V. P., \& Ong, B. H. (2009). Shape Preserving Approximation by Spatial Cubic Splines. Computer Aided Geometric Design, 26, 888903.

Mardawilis, Sunarminto, B. H., Shiddieq, D., \& Sudira, P. (2011). Evaluasi Kesesuaian Lahan untuk Pengembangan Tanaman Kedelai (Clycine max. L) pada Beberapa Tipe Klasifikasi Tanah. Jurnal Agronomika, 11 (1), 55-63. 
Marfai, M. A. (2012). Kajian Kesesuaian Lahan untuk Mendukung Pengembangan Komoditas Pertanian di Wilayah Perbatasan Negara Republik Indonesia (Studi Kasus di Kabupaten Merauke, Provinsi Papua). Jurnal Bumi Lestari, 12 (2), 260-267.

Marwoto \& Candra, D. S. (2007). Pembuatan Sistem Informasi Geografis Kesesuaian Lahan Tanaman Tebu Berbasis Web di Kabupaten Merauke. Jurnal Penginderaan Jauh, 4, 60-71.

Mokarram, M., \& Aminzadeh, F., (2010). GISBased Multicriteria Land Suitability Evaluation Using Ordered Weight Averaging with Fuzzy Quantifier: A Case Study in Shavur Plain, Iran", The International Archives of the Photogrammetry, Remote Sensing and Spatial Information Sciences, 38 (2), 508-512,

Mosleh, M. K., Hassan, Q. K., \& Chowdhury, E. H. (2015). Application of Remote Sensors in Mapping Rice Area and Forecasting Its Production: A Review. Sensors, 15, 769791.

Mitasova, H., Mitas, L., \& Harmon, R.S. (2005). Simultaneous Spline Approximation and Topographic Analysis for Lidar Elevation Data in Open-Source GIS. IEEE Geoscience and Remote Sensing Letters 2, 375-379.

Neteler, M., \& Mitasova, H. (2004). Open source GIS a GRASS GIS approach 2nd ed., Boston: Kluwer Academic Publishers.

Neteler, M, Bowman, M. H., Landa, M., \& Metz, M. (2012). GRASS GIS: A Multi-Purpose Open Source Gis. Environmental Modelling \& Software, 31, 124-130.

Pusat Penelitian Tanah dan Agroklimat (Puslittanak). 1993. Petunjuk Teknis Evaluasi Lahan, Bogor: Balitbang Pertanian, Departemen Pertanian.

Sarkar, A., Ghosh, A., \& Banik, P. (2014). MultiCriteria Land Evaluation for Suitability Analysis of Wheat: A Case Study of a Watershed in Eastern Plateau Region, India. Geo-Spatial Information Science, 17, 119128.

Wambrauw, E. V. (2015). Water Resource Management in the Lowlands of Southern Papua Using a Decision Support System and Integrating Traditional Ecological Knowledge. Thesis University of Auckland. 